\title{
Resolución del Consejo editorial de la revista THERYA
}

El consejo editorial de la revista THERYA ha decidido retirar el artículo "Juárez-Casillas, L. A., C. Varas, y F. A. Cervantes. 2013. Análisis filogenético del linaje evolutivo del oso negro (Ursus americanus). THERYA 4(3):467-484. DOI: 10.12933/therya-13-155", después del análisis de una serie de peticiones escritas presentadas al consejo editorial de la revista.

The editorial board of the journal THERYA has decided to retract the article "JuárezCasillas, L. A., C. Varas, y F. A. Cervantes. 2013. Phylogenetic analysis of the evolutionary lineage of Mexican black bears (Ursus americanus). THERYA 4(3):467-484. DOI: 10.12933/therya-13-155", after analyzing a written petition to the editorial board of the journal.

El retiro de este artículo se fundamenta en tres argumentos: 1) Existe un malentendido en la autoría y en la propiedad de los datos incluidos; 2) Uno de los co-autores no fue notificado, o bien, no estuvo al tanto del envió del artículo. Por lo tanto, no avala el contenido, 3) Se presentó una petición por escrito de uno de los co-autores. En dicha petición, se menciona que algunos de los datos genéticos no son correctos, lo que puede comprometer los resultados obtenidos. Es por ello que, ante la observación de estos hechos, el consejo editorial consideró más pertinente el retiro del artículo, que el difundir información que puede ser errónea.

The withdrawal of this article is based on three arguments: 1) There were misunderstandings about authorship and on ownership of the data included; 2) One of the co-authors was not notified or aware of this submittal and therefore did not endorse its contents. 3) A written petition was presented by one of the co-authors stating that some of the genetic data used are flawed. In combination, these points clearly compromise the results and veracity of this article. Given this lack of clarity, the editorial board is retracting this article in its entirety, rather than risking dissemination of erroneous information.

Atentamente/Sincerely

Consejo editorial de la revista THERYA

THERYA editorial board 
